\title{
Interlobar differences in bronchoalveolar lavage fluid from children with cystic fibrosis
}

\author{
J.P. Gutierrez*, K. Grimwood", D.S. Armstrong*, J.B. Carlin\#, R. Carzino`, A. Olinsky*, \\ C.F. Robertson*, P.D. Phelan",
}

Interlobar differences in bronchoalveolar lavage fluid from children with cystic fibrosis. J.P. Gutierrez, K. Grimwood, D.S. Armstrong, J.B. Carlin, R. Carzino, A. Olinsky, C.F. Robertson, P.D. Phelan. (C) ERS Journals Ltd 2001.

ABSTRACT: Bronchoalveolar lavage (BAL) performed in specialist centres has improved the understanding of infant cystic fibrosis (CF) lung disease. As most researchers sample from a single lobe, it was determined whether BAL results could be generalized to other lung segments.

Thirty-three CF children, aged 1.5-57 months, underwent in random order sequential BAL of their right middle and lingula lobes. Specimens from each lobe had separate quantitative bacteriology, cytology and cytokine analysis.

Bacterial counts $\geqslant 1 \times 10^{5}$ colony forming units (cfu) $\cdot \mathrm{mL}^{-1}$ were observed in nine $(27 \%)$ subjects, including six involving only the right middle lobe. These six children had similar inflammatory indices in their right middle and lingula lobes, and interleukin (IL)8 concentrations in the latter were significantly higher than that observed within the lingula lobes of the $24 \mathrm{CF}$ children with bacterial counts $<1 \times 10^{5} \mathrm{cfu} \cdot \mathrm{mL}^{-1}$. Lingula neutrophil and IL-8 levels correlated best with right middle lobe bacteria numbers.

This observational study in cystic fibrosis children suggests that while inflammation is detected in both lungs, bacterial distribution may be more inhomogeneous. Bronchoalveolar lavage microbiological findings from a single lobe may therefore, not be generalized to other lung segments. When performing bronchoalveolar lavage in cystic fibrosis children, it is important to sample from multiple sites.

Eur Respir J 2001; 17: 281-286.

\begin{abstract}
*Dept of Respiratory Medicine and the ${ }^{\#}$ Clinical Epidemiology and Biostatistics Unit, Murdoch Children's Research Institute, and Dept of Paediatrics, University of Melbourne, Parkville, Victoria, 3052, Australia.
\end{abstract}

Correspondence: K. Grimwood, Dept of Paediatrics, Wellington School of Medicine, PO Box 7343, Wellington 6015, New Zealand.

Fax: 6443855898

Keywords: Bacteria

bronchoalveolar lavage

child

cystic fibrosis

inflammation

Received: May 122000

Accepted after revision October 182000

This study was supported by grants from the Murdoch Children's Research Institute and the JB Were Charitable Fund, Melbourne, Australia.
While the lungs of newborn infants with cystic fibrosis (CF) are initially normal [1], changes in structure and function can occur at an early age [2, 3]. Flexible bronchoscopy with bronchoalveolar lavage (BAL) has allowed detection of both respiratory pathogens and inflammation in the lower airways of asymptomatic CF infants as young as 2-weeks [4]. Recently, some CF infants were found to have airway inflammation without respiratory pathogens being detected $[5,6]$. This led to speculation that the basic defect in CF itself may initiate inflammation [5-7]. However, in Melbourne, Australia, the authors were unable to confirm these observations [8]. Instead it was found that increasing bacterial numbers were associated with elevated inflammatory indices. Nevertheless, this was not a linear relationship, since inflammation increased significantly only after bacterial numbers reached $1 \times 10^{5}$ colony forming units (cfu) $\cdot \mathrm{mL}^{-1}$ [9]. Although BAL is routinely performed in both lungs and the samples pooled for analysis, most BAL studies in CF children sample from a single lobe, usually the lingula $[5,6,10,11]$. The authors hypothesized that sampling from a single lobe may fail to detect pathogens elsewhere in the lungs. By collecting samples from both lungs, and performing a separate analysis, it was determined whether BAL findings from a single lobe might be generalized to other regions.

\section{Methods}

\section{Subjects}

Since 1989 the state of Victoria, Australia has had a newborn $\mathrm{CF}$ screening programme [12]. The diagnosis is confirmed by either establishing homozygosity for the $\Delta$ F508 mutation or by sweat chloride concentrations $\geqslant 60 \mathrm{mmol} \cdot \mathrm{L}^{-1}$. All patients are managed by the Department of Respiratory Medicine at the Royal Children's Hospital, Melbourne.

From 1990, newly diagnosed infants were eligible for recruitment into a longitudinal population-based investigation of early CF lung disease $[4,8,9]$. Subjects underwent an initial, and then an annual, BAL to collect lower respiratory secretions. The Royal Children's 
Hospital Ethics in Human Research Committee approved the study and written informed consent was obtained from the parents or guardian of each child before bronchoscopy.

During an eight-month period, 33 consecutive $\mathrm{CF}$ infants and young children undergoing bronchoscopy as part of the longitudinal study were enrolled. None were receiving intravenous antibiotics or anti-inflammatory agents and seven (21\%) were newly diagnosed CF subjects having their first bronchoscopy.

In the infant $\mathrm{CF}$ patient population in the present study, BAL specimens pooled from both lungs have increased inflammatory indices when bacterial counts are $\geqslant 1 \times 10^{5} \mathrm{cfu} \cdot \mathrm{mL}^{-1}$ [9]. This diagnostic threshold was used to place subjects into one of two groups for further analysis. The clinical characteristics of the study participants are given in table 1. Although subjects with $\geqslant 1 \times 10^{5} \mathrm{cfu} \cdot \mathrm{mL}^{-1}$ were older, differences between the two groups were generally minor and not statistically significant.

\section{Bronchoalveolar lavage}

BAL was performed under general anaesthesia. Following application of topical lignocaine a flexible bronchoscope (Olympus model BF3 C20, external diameter $3.6 \mathrm{~mm}$, suction channel $1.2 \mathrm{~mm}$; Olympus Corporation of America, Hyde Park, NY, USA) was introduced into the lower airway through a laryngeal mask, avoiding the use of the suction channel until the tip of the bronchoscope was below the carina $[8,9]$. In random order, the tip was first wedged into either the right middle lobe or lingula bronchus. To optimize sampling from endobronchial sites a single small volume lavage was performed by instilling $1 \mathrm{~mL} \cdot \mathrm{kg}^{-1}$ (maximum $20 \mathrm{~mL}$ ) of sterile, nonbacteriostatic normal saline at room temperature through the suction channel over $2-3 \mathrm{~s}$. The saline was immediately aspirated into a sterile suction set over $10-20 \mathrm{~s}$ using negative pressures of $100-150 \mathrm{mmHg}$. The bronchoscope tip was wedged into the opposite bronchus next where a further single volume lavage was performed.

After induction of anaesthesia and before application of topical lignocaine to the vocal cords, a cotton-tipped swab was swept over the posterior oropharynx, tonsils and fauces. Blood was collected by venepuncture and allowed to clot at room temperature. The BAL fluid specimens from each lobe were kept separate and immediately transported on ice to the laboratory for processing.

\section{Microbiology}

As previously described [8,9], $500 \mu \mathrm{L}$ of BAL fluid was serially diluted onto six different media (horse blood, mannitol salt, MacConkey, chocolate bacitracin, cetrimide, and Burkholderia cepacia selective agar) for quantitative bacteriology, giving a lower detection limit of $1 \times 10^{1} \mathrm{cfu} \cdot \mathrm{mL}^{-1}$. Oropharyngeal swabs were streaked onto the same media. Subjects with respiratory symptoms also had their BAL and nasopharyngeal aspirates tested for respiratory viruses by direct fluorescent labelled antibodies and culture [13]. Respiratory bacterial pathogens were identified as Staphylococcus aureus, Haemophilus influenzae, Pseudomonas aeruginosa, Moraxella catarrhalis, Streptococcus pneumoniae, Burkholderia cepacia or Stenotrophomonas maltophilia. In contrast, Neisseria species, $\alpha$ haemolytic streptococci, Haemophilus (non-influenzae) species, diphtheroids and coagulase negative staphylococci were judged to be upper respiratory flora.

\section{Cytology and cytokine levels}

Total cell counts were determined on $100 \mu \mathrm{L}$ of uncentrifuged BAL fluid using a Neubauer haemocytometer counting chamber (Weber, Teddington, UK). Differential cell counts were estimated after centrifugation of a $300 \mu \mathrm{L}$ aliquot of BAL fluid at $72 \mathrm{~g}$ for 5 min in a Cytospin-2-cytocentrifuge (Shandon Southern Instruments, Sewick, PA, USA), Wright-Giemsa staining and counting cells at magnification under oil $\times 1,000$. The clotted blood and BAL fluid were centrifuged at $500 \mathrm{~g}$ for 5 -min at $4{ }^{\circ} \mathrm{C}$ and the supernatant immediately stored at $-70^{\circ} \mathrm{C}$ until the time of testing. The neutrophil chemokine interleukin (IL)-8 was measured by a double-sandwich, monoclonal enzyme immunoabsorbent assay which determined free and receptor bound IL-8 (Medgenix Diagnostics, Fleurus, Belgium). The assay detection limit was $0.7 \mathrm{pg} \cdot \mathrm{mL}^{-1}$.

As several studies report that urea and albumin diffuse into BAL fluid during bronchoscopy and

Table 1. - The clinical characteristics of the study participants

\begin{tabular}{|c|c|c|}
\hline & $\geqslant 1 \times 10^{5} \mathrm{cfu} \cdot \mathrm{mL}^{-1 \#}$ & $<1 \times 10^{5} \mathrm{cfu} \cdot \mathrm{mL}^{-1}$ \\
\hline Subjects $\mathrm{n}$ & 9 & 24 \\
\hline Age months & $35.3 \pm 21.3$ & $22.1 \pm 13.3$ \\
\hline Age range months & $3-57-$ & $1.5-50$ \\
\hline Sex $\%$ male & 33 & 54 \\
\hline \multicolumn{3}{|l|}{ CF genotype $\%$} \\
\hline Homozygous $\Delta \mathrm{F} 508$ & $7(78)$ & $16(67)$ \\
\hline Heterozygous $\Delta \mathrm{F} 508$ & $1(11)$ & $7(29)$ \\
\hline No copies $\Delta \mathrm{F} 508$ & $1(11)$ & $1(4)$ \\
\hline Respiratory symptoms \% & $8(89)$ & 19 (79) \\
\hline Oral antibiotics $\%$ & $6(67)$ & $12(50)$ \\
\hline
\end{tabular}

Data are presented as mean $\pm \mathrm{SD}$ or $\mathrm{n}(\%){ }^{\#}: 1 \times 10^{5}$ colony forming units of pathogenic bacteria $\cdot \mathrm{mL}^{-1}$ of bronchoalveolar lavage fluid from $\geqslant 1$ lobes [9]; ${ }^{\uparrow}$ oral antistaphylococcal antibiotics. $\mathrm{CF}$ : cyctic fibrosis. 
inflammatory states leading to overestimation of epithelial lining fluid volume [14], results are reported per $\mathrm{mL}$ of BAL fluid.

\section{Statistical analysis}

Data analysis was performed using Minitab Release 12 (Minitab Inc., State College, PA, USA). Pathogen and cell counts (per mL), and IL-8 concentrations, had strongly skewed distributions; following standard practice these were logarithmically transformed to approximate normality and summarized as geometric means with $95 \%$ confidence intervals (CI). Lymphocyte subset percentages were approximately symmetrically distributed and analysed without transformation. Within and between group comparisons for continuous variables were conducted using paired and two-sample t-tests respectively (in the log scale where appropriate). Proportions were compared by Chi-squared tests and associations between bacterial count, neutrophils and IL-8 were assessed using Spearman correlation.

\section{Results}

The results for each of the nine $\mathrm{CF}$ infants with $\geqslant 1 \times 10^{5} \mathrm{cfu} \cdot \mathrm{mL}^{-1}$ in their BAL fluid are shown in table 2. While BAL samples from three subjects had bacterial counts $\geqslant 1 \times 10^{5} \mathrm{cfu} \cdot \mathrm{mL}^{-1}$ from both lobes, another six had these pathogen numbers confined to the right middle lobe. In four subjects (numbers 1, 2, 3 and 5) there were large differences in bacterial load between the two sample sites. Except for subject 2, the nine infants had single pathogenic bacterial species detected in their BAL fluid cultures. Bacterial concordance between the lobes was observed in seven of the nine subjects and all, except subject 6, had the same pathogens isolated from both BAL and oropharyngeal cultures.

Thirty subjects had upper respiratory flora identified in at least one of their BAL cultures. The geometric mean colony counts of these nonpathogenic bacteria were similar in both right middle and lingula BAL specimens (4.5 versus $2.7 \times 10^{2} \mathrm{cfu} \cdot \mathrm{mL}^{-1}$ respectively) and did not vary with sample order. In contrast, respiratory viruses were not detected.

The right middle lobe was first in BAL sample order for $16(48 \%)$ subjects. Overall, there were no differences in sample volumes between the two lobes. The mean (standard deviation (SD); range) volume and mean percentage recovery BAL fluid values from both the right middle and lingula lobes were $7.2(4.4 ; 1-18)$ versus $7.9(4.6 ; 1-19) \mathrm{mL}$ and $41.9(15.9 ; 15-75) \%$ versus $43.7(15.7 ; 17-75) \%$ respectively. BAL profiles from the six $\mathrm{CF}$ infants with $\geqslant 1 \times 10^{5} \mathrm{cfu} \cdot \mathrm{mL}^{-1}$ detected only in their right middle lobes and the 24 $\mathrm{CF}$ subjects with $<1 \times 10^{5} \mathrm{cfu} \cdot \mathrm{mL}^{-1}$ are presented in table 3 . The BAL fluid inflammatory indices were elevated in both lobes from subjects with unilateral pathogen counts $\geqslant 1 \times 10^{5} \mathrm{cfu} \cdot \mathrm{mL}^{-1}$. Significant differences in selected right middle lobe inflammatory markers were present when these subjects were compared with infants whose counts were $<1 \times 10^{5} \mathrm{cfu} \cdot \mathrm{mL}^{-1}$. Similar differences were observed, reaching significance for IL-8, when the BAL inflammatory indices within the lingula lobes of the two groups were compared.

For all 33 subjects, right middle lobe bacterial pathogen numbers were significantly correlated with right middle lobe and lingula neutrophils $(\mathrm{r}=0.55$; $p<0.01$ versus $r=0.41 ; p<0.05)$ and IL-8 $(r=0.35$; $\mathrm{p}<0.05$ versus $\mathrm{r}=0.55 ; \mathrm{p}<0.01)$ values respectively. In

Table 2. - Cystic fibrosis subjects with $\geqslant 1 \times 10^{5} \mathrm{cfu} \cdot \mathrm{mL}^{-1}$ of bacteria in their bronchalveolar lavage

\begin{tabular}{|c|c|c|c|c|c|c|c|c|c|}
\hline $\begin{array}{l}\text { Nature of } \\
\text { infection }\end{array}$ & $\begin{array}{l}\text { Subject } \\
\text { number }\end{array}$ & $\begin{array}{c}\text { Age } \\
\text { months }\end{array}$ & Sex & Lobe & $\begin{array}{l}\text { BAL } \\
\text { order }\end{array}$ & Pathogen & $\mathrm{cfu} \cdot \mathrm{mL}^{-1 *}$ & $\% \mathrm{n}^{\#}$ & IL-8 $\mathrm{pg} \cdot \mathrm{mL}^{-1}$ \\
\hline \multirow[t]{15}{*}{ Focal } & \multirow[t]{2}{*}{1} & \multirow[t]{2}{*}{55} & \multirow[t]{2}{*}{$\mathrm{F}$} & RML & $1 \mathrm{st}$ & M. catarrhalis & $1 \times 10^{8}$ & 70 & 217 \\
\hline & & & & Lingula & 2 nd & M. catarrhalis & $1 \times 10^{4}$ & 73 & 135 \\
\hline & \multirow[t]{5}{*}{2} & \multirow[t]{5}{*}{52} & \multirow[t]{5}{*}{$\mathrm{F}$} & RML & 2nd & B. cepacia & $1 \times 10^{5}$ & 50 & 5968 \\
\hline & & & & & & H. influenzae & $1 \times 10^{4}$ & & \\
\hline & & & & & & S. aureus & $1 \times 10^{3}$ & & \\
\hline & & & & & & P. aeruginosa & $1 \times 10^{2}$ & & \\
\hline & & & & Lingula & $1 \mathrm{st}$ & H. influenzae & $1 \times 10^{2}$ & 43 & 1417 \\
\hline & \multirow[t]{2}{*}{3} & \multirow[t]{2}{*}{35} & \multirow[t]{2}{*}{$\mathrm{F}$} & RML & $1 \mathrm{st}$ & M. catarrhalis & $1 \times 10^{5}$ & 56 & 6300 \\
\hline & & & & Lingula & 2nd & No pathogens & - & 62 & 1493 \\
\hline & \multirow[t]{2}{*}{4} & \multirow[t]{2}{*}{24} & \multirow[t]{2}{*}{ M } & RML & $2 \mathrm{nd}$ & S. aureus & $1 \times 10^{6}$ & 77 & 362 \\
\hline & & & & Lingula & $1 \mathrm{st}$ & S. aureus & $1 \times 10^{4}$ & 17 & 878 \\
\hline & \multirow[t]{2}{*}{5} & \multirow[t]{2}{*}{3} & \multirow[t]{2}{*}{$\mathrm{M}$} & RML & $2 \mathrm{nd}$ & S. aureus & $1 \times 10^{5}$ & 69 & 1587 \\
\hline & & & & Lingula & $1 \mathrm{st}$ & S. aureus & $1 \times 10^{1}$ & 24 & 2922 \\
\hline & \multirow[t]{2}{*}{6} & \multirow[t]{2}{*}{37} & \multirow[t]{2}{*}{$\mathrm{F}$} & RML & 2 nd & P. aeruginosa & $1 \times 10^{5}$ & 80 & 389 \\
\hline & & & & Lingula & $1 \mathrm{st}$ & P. aeruginosa & $1 \times 10^{4}$ & 95 & 757 \\
\hline \multirow[t]{6}{*}{ Bilateral } & \multirow[t]{2}{*}{7} & \multirow[t]{2}{*}{57} & \multirow[t]{2}{*}{ M } & RML & $2 \mathrm{nd}$ & P. aeruginosa & $1 \times 10^{8}$ & 51 & 1672 \\
\hline & & & & Lingula & $1 \mathrm{st}$ & P. aeruginosa & $1 \times 10^{7}$ & 67 & 1436 \\
\hline & \multirow[t]{2}{*}{8} & \multirow[t]{2}{*}{52} & \multirow[t]{2}{*}{$\mathrm{F}$} & RML & 2nd & P. aeruginosa & $1 \times 10^{7}$ & 85 & 9805 \\
\hline & & & & Lingula & $1 \mathrm{st}$ & $P$. aeruginosa & $1 \times 10^{6}$ & 91 & 4908 \\
\hline & \multirow[t]{2}{*}{9} & \multirow[t]{2}{*}{3} & \multirow[t]{2}{*}{$\mathrm{F}$} & RML & $1 \mathrm{st}$ & M. catarrhalis & $1 \times 10^{6}$ & 51 & 372 \\
\hline & & & & Lingula & 2 nd & M. catarrhalis & $1 \times 10^{5}$ & 50 & 442 \\
\hline
\end{tabular}

*: Colony forming units $\cdot \mathrm{mL}^{-1}$ of bronchoalveolar lavage (BAL) fluid; ${ }^{*}$ : percentage neutrophils. RML: right middle lobe; IL-8: interleukin-8. 
Table 3. - Cystic fibrosis infant bronchoalveolar lavage profiles from the right middle and lingula lobes

\begin{tabular}{|c|c|c|c|c|c|}
\hline & \multicolumn{3}{|c|}{$\geqslant 1 \times 10^{5} \mathrm{cfu} \cdot \mathrm{mL}^{-1 *}$} & \multicolumn{2}{|c|}{$<1 \times 10^{5} \mathrm{cfu} \cdot \mathrm{mL}^{-1}$ in both lobes } \\
\hline & RML & p-value $e^{\#}$ & Lingula & RML & Lingula \\
\hline Subjects $n$ & \multicolumn{3}{|c|}{6} & \multicolumn{2}{|c|}{24} \\
\hline Recovery \% & 34 & 0.88 & 32 & 41 & 44 \\
\hline $\mathrm{CI}$ & $19-58$ & - & $23-45$ & $34-50$ & $36-51$ \\
\hline p-value & 0.42 & - & 0.09 & & \\
\hline Pathogen $\mathrm{cfu} \cdot \mathrm{mL}^{-1}$ & $4.6 \times 10^{5}$ & 0.003 & $3.2 \times 10^{2}$ & $2.6 \times 10^{1}$ & $2.1 \times 10^{1}$ \\
\hline CI & $2.5-86$ & - & $0.04-22.3$ & $0.4-11.6$ & $0.3-7.8$ \\
\hline p-value & $<0.001$ & - & 0.15 & - & - \\
\hline Total cell count $\times 10^{4} \cdot \mathrm{mL}^{-1}$ & 171 & 0.09 & 106 & 136 & 120 \\
\hline CI & $124-260$ & - & $42-265$ & $100-184$ & $83-172$ \\
\hline p-value & 0.19 & - & 0.77 & - & - \\
\hline Macrophages \% & 30 & 0.29 & 44 & 68 & 66 \\
\hline CI & $27-43$ & - & $12-75$ & $59-76$ & $59-74$ \\
\hline p-value & $<0.001$ & - & 0.14 & - & - \\
\hline Neutrophils \% & 67 & 0.29 & 52 & 28 & 29 \\
\hline CI & $55-79$ & - & $21-84$ & $21-35$ & $22-36$ \\
\hline p-value & $<0.001$ & - & 0.12 & - & - \\
\hline Lymphocytes \% & 4.0 & 0.85 & 3.8 & 3.0 & 3.2 \\
\hline CI & $0.4-7.6$ & - & $0.4-7.2$ & $1.9-4.0$ & $2.3-4.0$ \\
\hline p-value & 0.51 & - & 0.65 & - & - \\
\hline $\mathrm{IL}-8 \mathrm{pg} \cdot \mathrm{mL}^{-1}$ & 1104 & 0.67 & 906 & 229 & 175 \\
\hline & $233-5236$ & & $302-2716$ & $114-459$ & $108-283$ \\
\hline p-value & 0.05 & & 0.01 & - & - \\
\hline
\end{tabular}

*: $\geqslant 1 \times 10^{5} \mathrm{cfu} \cdot \mathrm{mL}^{-1}$ in the right middle lobe only; ${ }^{*}$ : paired t-test between right middle and lingula lobes in the 6 subjects with $\geqslant 1 \times 10^{5} \mathrm{cfu} \cdot \mathrm{mL}^{-1}$ in the right middle lobe only; $: 2$-sample t-test between right middle lobes and between lingula lobes in the 6 subjects with unilateral (right middle lobe only) bacterial counts $\geqslant 1 \times 10^{5} \mathrm{cfu} \cdot \mathrm{mL}^{-1}$ and the 24 subjects with $1 \times 10^{5} \mathrm{cfu} \cdot \mathrm{mL}^{-1}$ in both lobes. IL-8: interleukin-8.

contrast, numbers of pathogenic bacteria in the lingula correlated with the right middle lobe neutrophils $(\mathrm{r}=0.44 ; \mathrm{p}<0.01)$ and lingula IL-8 concentrations only $(\mathrm{r}=0.37 ; \mathrm{p}<0.05)$.

Although the IL- 8 concentration in several BAL samples was elevated, serum IL-8 levels remained low (range $3.3-8.1 \mathrm{pg} \cdot \mathrm{mL}^{-1}$ ) and there was no correlation between serum IL- 8 concentrations and pathogen numbers in BAL fluid.

\section{Discussion}

This study suggests that BAL findings from single lobes of $\mathrm{CF}$ infants may not represent changes found elsewhere within their lungs. While bacterial numbers can be unequally distributed, airway inflammation seems more pervasive. This may explain why single lobe BAL studies report some $\mathrm{CF}$ infants have inflammation in the absence of detectable organisms. Therefore, when performing BAL to study airway infection and inflammation in CF children, more than one site should be sampled.

Previous studies have reported that regional differences in disease parameters exist within CF lungs. Airway surface liquid composition varies between upper and lower airway sites [15] and lung pathology proceeds at variable rates with several regions injured at different times. This is supported by high-resolution computed tomography in CF infants showing bronchiectasis most commonly involves the upper lobes, particularly in the right lung [2]. These more severe changes within the upper lobes persist into adulthood [16], and are confirmed at autopsy [17].

Post mortem studies in adults have also shown that bacteria are not uniformly distributed throughout the CF lung [18]. Mucoid P. aeruginosa are abundant in the bronchioles, at sites of active inflammation and obliterative changes, but absent from areas of fibrosis or relatively well-preserved lung tissue [19]. Regional variations in bacterial load were recently reported in 12 stable adult $C F$ patients [20]. All had $1 \times 10^{5}-$ $1 \times 10^{8} \mathrm{cfu} \cdot \mathrm{mL}^{-1}$ of $P$. aeruginosa or $S$. aureus in BAL specimens from the right upper lobe. In contrast, these bacteria were not detected in the right middle or lower lobe samples of six subjects. However, inflammation was present in the upper lobes and also in lung segments where bacteria were absent or detected in lesser quantities. These findings are consistent with the data from the present study.

Why inflammation should develop within lung segments of a small number of subjects where bacteria cannot be grown by the usual culture techniques is unknown. This may result from bacteria being present in reduced numbers detectable only by molecular techniques or from persistence of products such as lipopolysaccharide [20, 21]. Others have observed a nonlinear relationship between bacterial load and airway inflammation [9, 22], and this suggests that inflammatory changes without detectable respiratory pathogens may be from a previously resolved infection [8].

There is also evidence for a more generalized airway inflammatory response to focal bacteria within the lung 
[20]. In a rat model of $P$. aeruginosa infection, installation of bacteria into the right lung resulted in local inflammation and cytokine release [23]. However, when large inocula were deployed, plasma cytokine levels increased and inflammatory changes developed in the opposite lung. Adult patients with severe unilateral pneumonia have raised cytokine concentrations in BAL specimens from the noninvolved lung [24]. Correlation between bacterial numbers in the right middle lobe and inflammation in the lingula suggests that systemic factors may influence local responses. Whether a critical threshold above which bacteria alter the integrity of the alveolar epithelial barrier, disrupting the compartmentalization of inflammatory mediators [25], is important in CF is uncertain. An association between serum IL-8 levels and bacterial numbers or inflammation was not observed. While studies in older CF patients with chronic lung disease report modest elevations of circulating inflammatory mediators [26, 27], these may only represent increased local production of cytokines and may not be of any pathophysiological significance.

Although quantitative bacteriology and a diagnostic threshold of $\geqslant 1 \times 10^{5} \mathrm{cfu} \cdot \mathrm{mL}^{-1}$ of pathogenic bacteria in $\mathrm{CF}$ children adjusts for potential upper airway contamination [9], this might not identify individuals with developing or partially treated infections or discriminate between resolving infection and other causes of airway inflammation. The concordant and increased bacterial numbers in the lingula BAL fluid from subjects 1, 4 and 6 suggest that infection may have been present in this lobe too. While this might explain some of the observations, subjects 2,3 , and 5 had large differences in bacterial numbers between the two lobes, but inflammatory changes remained at each of these sites.

Prospective recruitment of $\mathrm{CF}$ infants diagnosed by a newborn screening program allows the early detection of lung disease in an unselected population. As expected in this young study population, only $27 \%$ had large numbers of bacteria within their lower airways. The predominance of the right middle lobe as a site for bacteria might therefore, have arisen by sampling error or chance alone. However, the sampling order, percentage BAL returns and oropharyngeal flora counts were comparable between both groups of subjects. Significant contamination of the second BAL sample by remnants of the first sample within the bronchoscope seems unlikely, as there were no apparent order effects for either upper respiratory flora or pathogenic bacteria colony counts. Employing a relatively large aliquot of BAL fluid for culture, and using several plates containing selective or nonselective media reduced the risk of microbiological sampling errors. Similarly, using a single small volume bronchial lavage optimized the detection of endobronchial organisms and airway inflammation [28].

In the present study, nonbacterial causes of lingula inflammation seem unlikely. Aspiration from gastrooesophageal reflux most commonly involves the upper lobes [29], while the lingula is the least likely lobe to show bronchiectasis [2]. However, neither $\mathrm{pH}$ monitoring nor examination of BAL specimens for fat laden alveolar macrophages was undertaken.
To conclude, this observational study suggests that bacterial numbers within some infant cystic fibrosis lungs may not be uniform. In contrast signs of airway inflammation may be detected in more than one lobe. These findings are supported by experimental animal models and clinical and post mortem studies in adult cyctic fibrosis subjects. Bronchoalveolar lavage microbiological results from a single lobe may not therefore, always represent findings in other regions of the lungs. This could explain why some infant single lobe bronchoalveolar lavage studies have reported inflammation in the absence of detectable respiratory pathogens. It emphasizes the importance of sampling from multiple lung segments or lobes when using bronchoalveolar lavage to study cystic fibrosis lung disease.

\footnotetext{
Acknowledgements. The authors gratefully acknowledge the support of K. Brown and the staff of the Anaesthetic Dept of the Royal Children's Hospital for their continued support of this project.
}

\section{References}

1. McGrath SA, Basu A, Zeitlin PL. Cystic fibrosis gene and protein expression during fetal lung development. Am J Respir Cell Mol Biol 1993; 8: 201-208.

2. Stiglbauer R, Schurawitzki H, Eichler I, Vergesslich KA, Götz M. High-resolution CT in children with cystic fibrosis. Acta Radiologica 1992; 33: 548-553.

3. Tepper RS, Montgomery GL, Ackerman V, Eigen H. Longitudinal evaluation of pulmonary function in infants and very young children with cystic fibrosis. Pediatr Pulmonol 1993; 16: 96-100.

4. Armstrong DS, Grimwood K, Carzino R, Carlin JB, Olinsky A, Phelan PD. Lower respiratory infection and inflammation in infants with newly diagnosed cystic fibrosis. BMJ 1995; 310: $1571-1572$.

5. Khan TZ, Wagener JS, Bost T, Martinez J, Accurso FJ, Riches DWH. Early pulmonary inflammation in infants with cystic fibrosis. Am J Respir Crit Care Med 1995; 151: $1075-1082$.

6. Balough K, McCubbin M, Weinberger M, Smits W, Aherns R, Fick R. The relationship between infection and inflammation in the early stages of lung disease from cystic fibrosis. Pediatr Pulmonol 1995; 20: 63-70.

7. Cantin A. Cystic fibrosis lung inflammation: early, sustained, and severe. Am J Respir Crit Care Med 1995; 151: 939-941.

8. Armstrong DS, Grimwood K, Carlin JB, et al. Lower airway inflammation in infants and young children with cystic fibrosis. Am J Respir Crit Care Med 1997; 156: $1197-1204$.

9. Armstrong DS, Grimwood K, Carlin JB, Carzino R, Olinsky A, Phelan PD. Bronchoalveolar lavage or oropharyngeal cultures to identify lower respiratory pathogens in infants with cystic fibrosis. Pediatr Pulmonol 1996; 21: 267-275.

10. Wilmott RW, Kassab JT, Kilian PL, Benjamin WR, Douglas SR, Wood RE. Increased levels of interleukin-1 in bronchoalveolar washings from children with bacterial pulmonary infections. $\mathrm{Am}$ Rev Respir Dis 1990; 142: 365-368. 
11. Birrer P, McElvaney NG, Rudeberg A, et al. Proteaseantiprotease imbalance in the lungs of children with cystic fibrosis. Am J Respir Crit Care Med 1994; 150: 207-213.

12. Massie RJ, Olsen M, Glazner J, Robertson CF, Francis I. Newborn screening for cystic fibrosis in Victoria: 10 years' experience (1989-1998). Med J Aust 2000; 172: $584-587$.

13. Armstrong D, Grimwood K, Carlin J, et al. Severe viral respiratory infections in infants with cystic fibrosis. Pediatr Pulmonol 1998; 26: 371-379.

14. Walters EH, Gardiner PV. Bronchoalveolar lavage as a research tool. Thorax 1991; 46: 613-618.

15. Hull J, Skinner W, Robertson C, Phelan P. Elemental content of airway surface liquid from infants with cystic fibrosis. Am J Respir Crit Care Med 1998; 157: $10-14$.

16. Maffessanti MD, Candusso M, Brizzi F, Piovesana F. Cystic fibrosis in children: HRCT findings and distribution of disease. $J$ Thorac Imag 1996; 11 $27-38$.

17. Tomashefski JF, Bruce M, Goldberg HI, Dearborn DG. Regional distribution of macroscopic lung disease in cystic fibrosis. Am Rev Respir Dis 1986; 133: $535-$ 540.

18. Smith DL, Smith EG, Pitt TL, Stableforth DE. Regional microbiology of the cystic fibrosis lung: a post-mortem study in adults. J Infection 1998; 37: 41 43.

19. Baltimore RS, Christie CDC, Walker-Smith GJ. Immunohistopathologic localization of Pseudomonas aeruginosa in lungs from patients with cystic fibrosis. Am Rev Respir Dis 1989; 140: 1650-1661.

20. Meyer KC, Sharma A, Rosenthal NS, Peterson K, Brennan L. Regional variability of lung inflammation in cystic fibrosis. Am J Respir Crit Care Med 1997; 156: $1536-1540$.

21. Copenhaver S, Sage A, Vasil A, et al. BALF PCR and
ELISA identification on non-culturable Pseudomonas aeruginosa in infants and toddlers with cystic fibrosis. Pediatr Pulmonol 1996; 22: Suppl.13, 291-292.

22. Muhlebach MS, Stewart PW, Leigh MW, Noah TL. Quantitation of inflammatory responses to bacteria in young cystic fibrosis and control patients. Am J Respir Crit Care Med 1999; 160: 186-191.

23. Terashima T, Matsubara H, Nakamura M, et al. Local Pseudomonas installation induces contralateral lung injury and plasma cytokines. Am J Respir Crit Care Med 1996; 153: $1600-1605$.

24. Headley AS, Tolley E, Meduri GU. Infections and the inflammatory response in acute respiratory distress syndrome. Chest 1997; 111: $1306-1321$.

25. Tutor JD, Mason CM, Dobard E, Beckerman RC, Summer WS, Nelson S. Loss of compartmentalization of alveolar tumor necrosis factor after lung injury. Am J Respir Crit Care Med 1994; 149: 1107-1111.

26. Wilmott RW, Frenzke M, Kociela V, Peng L. Plasma interleukin-l $\alpha$ and $\beta$, tumor necrosis factor- $\alpha$, and lipopolysaccharide concentrations during pulmonary exacerbations of cystic fibrosis. Pediatr Pulmonol 1994; 18: $21-27$.

27. Nixon LS, Yung B, Bell SC, Elborn JS, Shale DJ. Circulating immunoreactive interleukin-6 in cystic fibrosis. Am J Respir Crit Care Med 1998; 157: $1764-1769$.

28. Ratjen F, Rietschel E, Griese M, Ballmann M, Kleinau I, Doring G, Reinhardt D, Paul K, for the bronchoalveolar lavage for the evaluation of antiinflammatory treatment (BEAT) study group. Fractional analysis of bronchoalveolar lavage fluid cytology in cystic fibrosis patients with normal lung function. Eur Respir $J$ 2000; 15: $141-145$.

29. Button BM, Heine RG, Catto-Smith AG, Phelan PD, Olinsky A. Postural drainage and gastro-oesophageal reflux in infants with cystic fibrosis. Arch Dis Child 1997; 76: $148-150$. 